\title{
PRICE RISK MANAGEMENT IN THE WHEAT MARKET USING OPTION STRATEGIES
}

\author{
Martina Bobriková ${ }^{1}$ \\ *Corresponding author E-mail: martina.bobrikova@tuke.sk
}

\begin{abstract}
A R T I C L E I N F O
A B S T R A C T

Review Article

Recently, the agricultural business is displayed a greater

Received: 22 January 2021

Accepted: 01 June 2021

amount of risk because of price volatility growth. Consequently, it is necessary to have knowledge of how to regulate the risk of price fluctuations. This paper is doi:10.5937/ekoPolj2102449B

UDC 005.334:005.21]:

$[336.763+633.11$

Keywords:

price risk management, agricultural market, vanilla option, option strategies, volatility concerned with the hedging techniques in the commodity market by the help of vanilla options. The main idea is to analyze option strategies with the ambition to demonstrate their utilization by hedging against increasing prices. Hedged buying price formulas are derived for every spot futures price. An additional contribution is considered for applying in the wheat trading. Chicago Mercantile Exchange products, i.e. wheat options on futures are investigated. The profitability of hedged scenarios is examined. A comparative analysis of the designed hedging variants is presented. Suggestions for potential wheat

JEL: $G 130$ buyers are proposed.
\end{abstract}

(C) 2021 EA. All rights reserved.

\section{Introduction}

Over last decades, individuals and firms are connected with the price movements of agricultural products (wheat, corn, soybean etc.). Price risk management is beginning to be investigated for protective objectives. In line with the Covid-19 pandemic, prices in commodity market are very volatile and prices of most agricultural commodities are trended higher. The commodity market participants are pointed at the commodity price risk management, i.e., hedging. Hedging techniques used to manage commodity price risk are concerned with the potential scenarios for the futures commodity price development. Assume that the commodity buyer anticipates spot commodity price increase in the future. He selects the hedging against a future price fluctuation with aim to ensure acceptable buying price of a commodity. The main idea of hedging is to create hedged position using derivatives, especially options. Taleb (1997) characterizes derivatives as tools whose value depends on the value of some underlying asset. According to Hull (2011) an option indicates a right to buy (call option) or a right

1 Martina Bobrikova, Ph.D., Assistant Professor, Faculty of Economics, Technical University od Kosice, Nemcova 32, 04001 Kosice, Slovak Republic, Phone: +421 5560221 46, E-mail: martina.bobrikova@tuke.sk, ORCID ID (https://orcid.org/0000-0002-3116-5786) 
to sell (put option) an underlying asset at a strike price in a maturity for an option premium, i.e., price of an option. American-style options on agricultural commodity futures contract are available on the agricultural market. The buyer of call or put option can select various strike prices and maturities. Papers Cohen (2005); Hull (2019 and 2011); Kolb and Overdahl (2010) presents option strategies.

Nowadays, many scientific papers focus on price hedging. For example, agricultural producers can manage commodity risk following an unpredictable price development (see, e.g., Taušer, Čajka, 2014; Timková, 2018). Kuzman et al. (2018) studied derivatives and their trading in the context of agricultural sector. Also, Garcia, Leuthold (2004) dealt with agricultural commodity futures and options. Harčariková, Šoltés (2016); Harčariková, Šoltés (2017) investigated the hedging techniques in energy sector using option strategies created by vanilla and exotic options. For example, studies Šoltés, Harčariková (2015); Šoltés, Harčariková (2016); Timková, Šoltés (2019) analyzed new hedging option strategies. Djordjevic (2018) showed how weather derivatives are used to hedge in Winter Ski Tourism. On the other hand, Harčariková (2015) used derivatives in the design of new outperformance certificates in agricultural market. Investment certificates represent an innovative financial product suitable for every type of investor. Harčariková, Bánociová (2015); Šoltés, Harčariková (2015); Šoltés, Harčariková (2017); Šoltés et al. (2019), Timková (2016) analyzed using of options to the investment certificates formation.

Based on financial engineering principles, we analyze the option strategies and propose hedging possibilities. The purpose is to integrate options into the effective risk management strategies by agricultural buyers. Buyer are potential hedgers against a price growth. Following the review of existing theoretical framework mentioned above, this paper is focused on the application to real-traded Chicago Mercantile Exchange (CME) products, i.e., wheat plain vanilla options on futures.

The primary aim is to analyze option hedging strategies against increasing markets, i.e., Long Call, Short Combo and Vertical Ratio Call Back Spread strategy and perform their comparative analysis. The payoff profiles of individual vanilla option are used in the option strategy formation. Hedging variants available for managing a price growth hedge a maximum buying price, i.e., buying price ceiling. The profitability of the proposed hedging variants for all possible intervals of spot prices ate the maturity date is performed. The comparative analysis is presented as well. The suggestion for the potential buyers is indicated.

\section{Materials and methods}

Options as a type of derivative are new tools for potential investors and hedgers. These instruments can protect against price movements and are often used in the price risk hedging. Commodity options are options on futures contracts.

A futures contract is an agreement to buy or sell some underlying asset (e.g., commodity) during the maturity. All conditions of the commitment are standardized excepting the price. 
The nature of the hedging with options on futures is in taking an opposite position in the spot market and futures market. The movement between the spot price and future price is not necessary equivalent and it is known as a basis. The basis at the specific date represents the distinction of spot and futures price. Positive basis change is illustrated in Table 1. Wheat spot price is at $\$ 6.20$ per bushel and wheat futures price is at $\$ 6.50$ per bushel in October 2020. The basis is $\$ 0.30$ (\$6.20 - \$6.50). The buyer of wheat expects the price growth in the future. Therefore, he decides to buy September 2021 wheat futures contract at $\$ 6.50$ per bushel in October 2020. Assume spot market price increase by $\$ 0.50$ per bushel and futures price increase by $\$ 0.45$ per bushel in August 2021. The basis is $\$ 0.25$ under $(\$ 6.70$ - $\$ 6.95)$. The buyer sells September wheat futures contract at $\$ 6.95$ per bushel. Because the change on futures market position $(\$ 0.45$ per bushel) is lower than the change on the spot market position ( $\$ 0.45$ per bushel), the buying price is $\$ 6.15$ per bushel.

Table 1. Basis change

\begin{tabular}{|l|c|c|c|c|c|}
\hline & $\begin{array}{c}\text { Wheat spot } \\
\text { market } \\
\text { position }\end{array}$ & $\begin{array}{c}\text { Wheat spot } \\
\text { price }\end{array}$ & $\begin{array}{c}\text { Wheat futures market } \\
\text { position }\end{array}$ & $\begin{array}{c}\text { Wheat } \\
\text { futures } \\
\text { price }\end{array}$ & Basis \\
\hline October 2020 & - & $\$ 6.20$ & $\begin{array}{c}\text { buy September wheat } \\
\text { futures contract }\end{array}$ & $\$ 6.50$ & $\$-0.30$ \\
\hline August 2021 & buy wheat & $\$ 6.70$ & $\begin{array}{c}\text { sell September wheat } \\
\text { futures contract }\end{array}$ & $\$ 6.95$ & $\$-0.25$ \\
\hline Change & - & $\$-0.50$ & - & $\$+0.45$ & $\$+0.05$ \\
\hline Buying price & - & - & - & - & $\$ 6.15$ \\
\hline
\end{tabular}

Source: Authors' calculations

Assume the agricultural buyer expects the wheat price increase in the future and decides to hedge using option strategies. Option strategies using in the risk management of the price growth are shown in Table 2. These strategies secure the maximum buying price for all possible futures price scenarios.

Table 2. Option strategies against a price increase

\begin{tabular}{|l|c|c|}
\hline & Volatility & Risk \\
\hline Long Call & bullish & low \\
\hline Short Combo & bullish & high \\
\hline Vertical Ratio Call Back Spread & bullish & low \\
\hline
\end{tabular}

Source: Authors' summary

Strategies noted above provide different risk management benefits for commodity buyers. The selection of the most effective price risk management is a process based on price expectation and investor's attitude to profit/risk. In this point of view, each strategy is characterized by some strengths and weaknesses, which the traders must identify if they decide to get into the hedging strategy. The part of results introduces option strategies used in the risk management as a hedging tool. 
The approach is established on the payoff profile of option strategies Long Call, Shor Combo and Vertical Ratio Call Back Spread Strategy. Option strategies are formed by wheat options on futures contract. Futures contracts are more liquid and easier to trade than the underlying asset (wheat). We analyze and compare mentioned option strategies as a potential instrument to hedge a price growth in the wheat market.

The proposed hedging possibilities are applied to the wheat futures American-style options contract referred to September 2021. Table 3 illustrates the call and put option premiums from October $\left(14^{\text {th }}\right.$ October 2020 is the settlement date $)$. All data are Obtained from the CME Group and one wheat option contract size is standardized as 5000 bushels.

Table 3. Call and put option premiums of wheat options on futures

\begin{tabular}{|c|c|c|}
\hline Call option premium \$/per bushel & Strike price \$/per bushel & Put option premium \$/per bushel \\
\hline 0.762 & 5.70 & 0.234 \\
\hline 0.700 & 5.80 & 0.273 \\
\hline 0.643 & 5.90 & 0.315 \\
\hline 0.590 & 6.00 & 0.365 \\
\hline 0.541 & 6.10 & 0.413 \\
\hline 0.495 & 6.20 & 0.467 \\
\hline 0.454 & 6.30 & 0.526 \\
\hline 0.416 & 6.40 & 0.590 \\
\hline 0.382 & 6.50 & 0.654 \\
\hline 0.350 & 6.60 & 0.722 \\
\hline
\end{tabular}

Source: CME Group

The dataset consists of 10 real-traded vanilla call and put options. The strike prices of call and put options are in the range of 5.7 - 6.6. The currency is in $\$ /$ per bushel. The prices per bushel are considered. Calculations do not consider transaction and any others charges. Basis $\$ 0$.

\section{Results}

The main goal was to investigate the option hedging strategies against a price increase in the case of wheat market. We provided the analyses of hedging strategies and their comparison. The wheat buyer made the profit from the futures market position in order to cover the loss from the spot market position.

The first strategy which can be used in the price risk management is Long Call strategy (referred as LC). Long Call is elementary bullish strategy. By Long Call the option buyer has the right to buy a wheat futures contract at a strike price $\mathrm{X}$ at any time $\mathrm{T}$ during a maturity period. The buyer pays an option premium $c_{L}$ to the option seller for the right of choice.

Option position is hedging instrument without physical delivery of the wheat in the futures market. The hedged price is the sum of the unhedged spot futures price at the time $\mathrm{T}$ and the payoff given by the option strategy hedged position. Table 4 shows the unhedged and hedged buying price by Long Call strategy. 
Table 4. Hedged buying price by Long Call strategy

\begin{tabular}{|c|c|c|c|}
\hline Commodity price range & Unhedged price & Payoff from strategy & Hedged price \\
\hline $\mathrm{S}_{\mathrm{T}}<\mathrm{X}$ & $-\mathrm{S}_{\mathrm{T}}$ & $-\mathrm{c}_{\mathrm{L}}$ & $-\mathrm{S}_{\mathrm{T}_{\mathrm{T}}}-\mathrm{c}_{\mathrm{L}_{\mathrm{L}}}$ \\
\hline $\mathrm{S}_{\mathrm{T}} \geq \mathrm{X}$ & $-\mathrm{S}_{\mathrm{T}}$ & $\mathrm{S}_{\mathrm{T}}-\mathrm{X}-\mathrm{c}_{\mathrm{L}_{\mathrm{L}}}$ & $-\mathrm{X}-\mathrm{c}_{\mathrm{L}_{\mathrm{L}}}$ \\
\hline
\end{tabular}

Source: Authors' summary

Two scenarios can occur at the specific date in the future. If the spot price at the future date $\mathrm{S}_{\mathrm{T}}$ is lower than the strike price, than the buyer will hedge the price $-\mathrm{S}_{\mathrm{T}}-\mathrm{p}_{\mathrm{L}}$. Otherwise, the call option will not be exercise and the buyer will hedge the price $-\mathrm{X}-\mathrm{c}_{\mathrm{L}}$. The profit of hedging by Long Call strategy will gain if the price increases above $-\mathrm{X}-\mathrm{c}_{\mathrm{L}}$. The premium in the amount $\mathrm{c}_{\mathrm{L}}$ represents the maximum loss of hedging by Long Call strategy.

It was expected buying of September Wheat call option contract at the strike price $\$ 6.2$ per bushel for the option premium $\$ 0.467$ per bushel. Table 5 illustrates hedged price and profit/loss from hedging as the difference between the final hedged wheat price and unhedged price at the future date T. If the difference is positive (more than 0 ), the hedged position is better than the unsecured position. Otherwise, if the difference is negative (less than 0), than the unsecured position is better. The comparison of the proposed hedging variants with the unhedged position based on the results noted into Table 5 is graphically illustrated in Figure 1.

Table 5. Hedged wheat buying price by Long Call strategy

\begin{tabular}{|c|c|c|c|c|c|}
\hline Commodity price range & Hedged price & \multicolumn{2}{|c|}{ Profit of hedging } & \multicolumn{2}{c|}{ Loss of hedging } \\
\hline & & Min & Max & Min & Max \\
\hline $\mathrm{S}_{\mathrm{T}}<6.2$ & $-\mathrm{S}_{\mathrm{T}}-0.467$ & - & - & 0.467 & 0.467 \\
\hline $6.2 \leq \mathrm{S}_{\mathrm{T}} \geq 6.667$ & 6.667 & - & - & 0 & 0.467 \\
\hline $6.667 \leq \mathrm{S}_{\mathrm{T}}$ & 6.667 & 0 & $\infty$ & - & - \\
\hline
\end{tabular}

Source: Authors' calculations

Figure 1. Hedged and unhedged wheat buying price by Long Call strategy

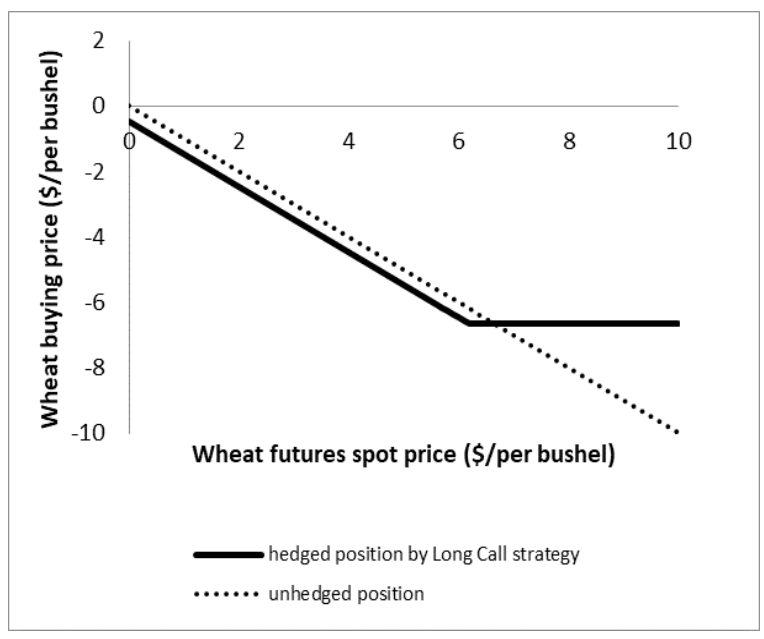

Source: Authors' calculations 
If it was expected that the producer buyed a September wheat call option contract at the strike price $\$ 6.60$ per bushel for the option premium $\$ 0.350$ per bushel. The higher ceiling price level $\$ 6.667$ per bushel would be established by the commodity buyer. Using options with various strike prices we could obtain different buying prices (see Figure 2). The price sensitivity of the specific strategy could be calculated. The higher strike price was, the lower call option premium was. If the strike price was lower, higher costs were needed for buying of options and therefore the lower buying price ceiling was ensured. Using Long Call strategy, the producer limited the maximum buying price without giving up the possibility to participate in the price drop.

Figure 2. Comparison of hedged positions by Long Call strategy with various strike prices

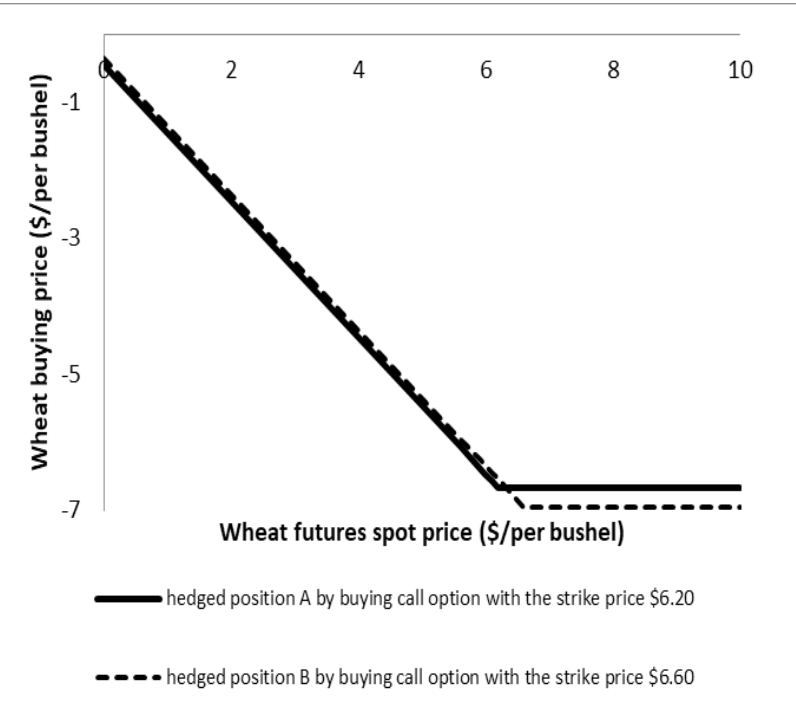

Source: Authors' calculations

Short Combo (referred as SC) is a bullish strategy that can be formed zero-cost. This strategy consists of selling a put option with a lower strike price $\mathrm{X}_{1}$ and option premium $\mathrm{p}_{\mathrm{S} 1}$ and buying a call option on the same wheat futures contract with a higher strike price $\mathrm{X}_{2}$ and option premium $\mathrm{c}_{\mathrm{L} 2}$ (see Table 6).

Table 6. Hedged wheat buying price by Short Combo strategy

\begin{tabular}{|c|c|c|c|}
\hline Commodity price range & Unhedged price & Payoff from strategy & Hedged price \\
\hline $\mathrm{S}_{\mathrm{T}}<\mathrm{X}_{1}$ & $-\mathrm{S}_{\mathrm{T}}$ & $\mathrm{S}_{\mathrm{T}}-\mathrm{X}_{1}+\mathrm{p}_{\mathrm{S}_{1}}-\mathrm{c}_{\mathrm{L}}$ & $-\mathrm{X}_{1}+\mathrm{p}_{\mathrm{S}_{1}}-\mathrm{c}_{\mathrm{L}}$ \\
\hline $\mathrm{X}_{1}<\mathrm{S}_{\mathrm{T}} \leq \mathrm{X}_{2}$ & $-\mathrm{S}_{\mathrm{T}}$ & $\mathrm{P}_{\mathrm{S} 1}-\mathrm{c}_{\mathrm{L} 2}$ & $-\mathrm{S}_{\mathrm{T}}+\mathrm{p}_{\mathrm{S} 1}-\mathrm{c}_{\mathrm{L} 2}$ \\
\hline $\mathrm{S}_{\mathrm{T}} \geq \mathrm{X}_{2}$ & $-\mathrm{S}_{\mathrm{T}}$ & $\mathrm{S}_{\mathrm{T}}-\mathrm{X}_{2}+\mathrm{p}_{\mathrm{S} 1}-\mathrm{c}_{\mathrm{I} 2}$ & $-\mathrm{X}_{2}+\mathrm{p}_{\mathrm{S} 1}-\mathrm{c}_{\mathrm{I} 2}$ \\
\hline
\end{tabular}

Source: Authors' summary

It was expected to buy a September Wheat put option contract at the strike price $\$ 5.90$ per bushel for the option premium $\$ 0.643$ per bushel and at the same time to buy a September Wheat call option contract at the strike price $\$ 6.20$ per bushel for the option premium $\$ 0.467$ per bushel (see Table 7 and Figure 3). 
Table 7. Hedged wheat buying price by Short Combo strategy

\begin{tabular}{|c|c|c|c|c|c|}
\hline Commodity price range & Hedged price & \multicolumn{2}{|c|}{ Profit of hedging } & \multicolumn{2}{c|}{ Loss of hedging } \\
\hline & & Min & Max & Min & Max \\
\hline $\mathrm{S}_{\mathrm{T}}<5.724$ & -5.724 & - & - & 0 & 5.724 \\
\hline $5.724 \leq \mathrm{S}_{\mathrm{T}}<5.9$ & -5.724 & 0 & 0.176 & - & - \\
\hline $5.9 \leq \mathrm{S}_{\mathrm{T}}<6.2$ & $-\mathrm{S}_{\mathrm{T}}+0.176$ & 0.176 & 0.176 & - & - \\
\hline $6.2 \leq \mathrm{S}_{\mathrm{T}}$ & -6.024 & 0 & $\infty$ & - & - \\
\hline
\end{tabular}

Source: Authors' summary

Figure 3. Hedged and unhedged wheat buying price by Short Combo strategy

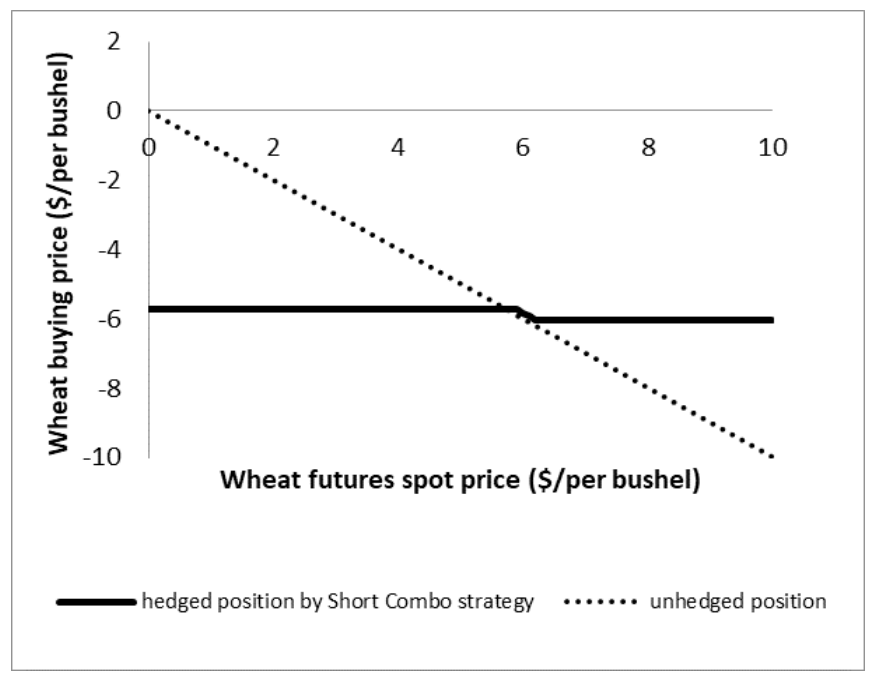

Source: Authors' calculations

In previous table and figure are shown the data for Short Combo strategy. By Short Combo, the agricultural hedger secured a lower price level ceiling because of the premium received for selling the put. But Short Put position limited the opportunity to participate in the price drop by establishing a price level floor. This buying price range was determined by the strike prices. Therefore, the choice of appropriate strike prices is very important in hedging process. The greater the difference between the put and call strike prices, the wider the buying price range.

Next variant of Short Combo was created with the strike prices $\$ 6.2$ per bushel and $\$ 6.6$ per bushel. Also, the combination of these strike prices was selected without any initial cost (initial profit is $\$ 0.117$ per bushel), which causes the higher maximum buying price at $\$ 6.483$ per bushel. Comparison of these two hedging variants is illustrated in Figure 4. In the case of decreasing wheat price, the strategy B hedged the higher price floor, i.e., it was better than the strategy A. 
Figure 4. Comparison of hedged positions by Short Combo strategy A and B

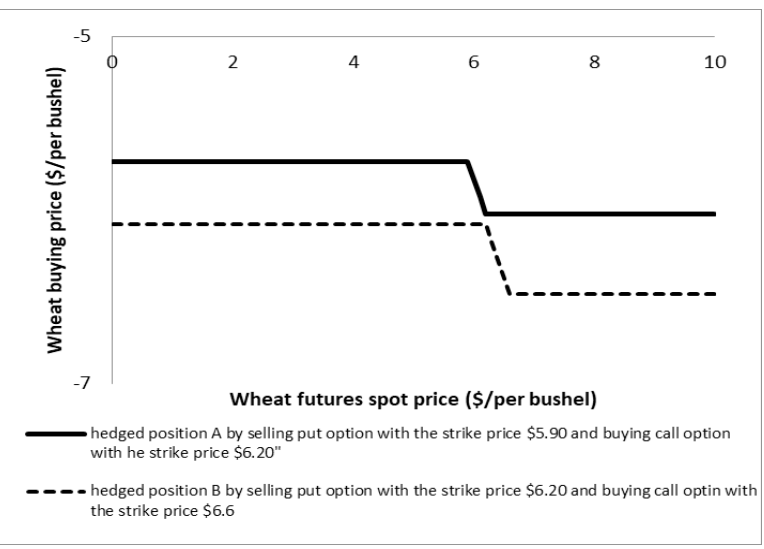

Source: Authors' calculations

Vertical Ratio Call Back Spread strategy (referred as VRCBS) is spread option strategy created by selling a lower number of call options $n_{1}$ with a lower strike price $X_{1}$ maturity date TR and option premium $\mathrm{c}_{\mathrm{S} 1}$ and at the same time by buying a higher number of call option $\mathrm{n}_{2}$ on the same wheat futures contract with a strike price $\mathrm{X}_{2}$, maturity date $\mathrm{T}$ and option premium $\mathrm{c}_{\mathrm{L} 2}$ (see Table 8). If the following condition is satisfied $\mathrm{n}_{1} \mathrm{c}_{\mathrm{S} 1}-\mathrm{n}_{2} \mathrm{c}_{\mathrm{L} 2}>0$, then no additional costs are needed for the formation of Vertical Ratio Call Back Spread strategy, i.e., it is a zero-cost strategy.

Table 8. Hedged wheat buying price by Vertical Ratio Call Back Spread strategy

\begin{tabular}{|c|c|c|c|}
\hline $\begin{array}{c}\text { Commodity } \\
\text { price range }\end{array}$ & $\begin{array}{c}\text { Unhedged } \\
\text { price }\end{array}$ & Payoff from strategy & Hedged price \\
\hline $\mathrm{S}_{\mathrm{T}}<\mathrm{X}_{1}$ & $-\mathrm{S}_{\mathrm{T}}$ & $\mathrm{n}_{1} * \mathrm{c}_{\mathrm{S} 1}-\mathrm{n}_{2} * \mathrm{c}_{\mathrm{L} 2}$ & $-\mathrm{n}^{*} \mathrm{~S}_{\mathrm{T}}+\mathrm{n}_{1} * \mathrm{c}_{\mathrm{c}_{1}}-\mathrm{n}_{2} * \mathrm{c}_{\mathrm{L} 2}$ \\
\hline $\mathrm{X}_{1}<\mathrm{S}_{\mathrm{T}} \leq \mathrm{X}_{2}$ & $-\mathrm{S}_{\mathrm{T}}$ & $-\mathrm{n}_{1} * \mathrm{~S}_{\mathrm{T}}+\mathrm{n}_{1} * \mathrm{X}_{1}+\mathrm{n}_{1} * \mathrm{c}_{\mathrm{S} 1}-\mathrm{n}_{2} * \mathrm{c}_{\mathrm{L} 2}$ & $-\mathrm{n}^{*} \mathrm{~S}_{\mathrm{T}}+\mathrm{n}_{1} * \mathrm{~S}_{\mathrm{T}}+\mathrm{n}_{1} * \mathrm{X}_{1}+\mathrm{n}_{1} * \mathrm{c}_{\mathrm{S} 1}{ }^{-}$ \\
\hline $\mathrm{S}_{\mathrm{T}} \geq \mathrm{X}_{2}$ & $-\mathrm{S}_{\mathrm{T}}$ & $\left(\mathrm{n}_{2}-\mathrm{n}_{1}\right) * \mathrm{~S}_{\mathrm{T}}+\mathrm{n}_{1} * \mathrm{X}_{1}-\mathrm{n}_{2} * \mathrm{X}_{2}+\mathrm{n}_{1} * \mathrm{c}_{\mathrm{S} 1}-\mathrm{n}_{2} * \mathrm{c}_{\mathrm{L} 2}$ & $\mathrm{n}_{1} * \mathrm{X}_{1}-\mathrm{n}_{2} * \mathrm{X}_{2}+\mathrm{n}_{1} * \mathrm{c}_{\mathrm{S} 1}-\mathrm{n}_{2} * \mathrm{c}_{\mathrm{L} 2}$ \\
\hline
\end{tabular}

Source: Authors' summary

It was expected the producer sell 1 May Wheat call option at the strike price $\$ 5.90$ per bushel for the option premium $\$ 0.643$ per bushel and at the same time buy 2 May Wheat call options at the strike price $\$ 6.20$ per bushel for the option premium $\$ 0.495$ per bushel. Based on the data, the following parameters in Table 9 were calculated.

Table 9. Hedged wheat buying price by Vertical Ratio Call Back Spread strategy

\begin{tabular}{|c|c|c|c|c|c|}
\hline Commodity price range & Hedged price & \multicolumn{2}{|c|}{ Profit of hedging } & \multicolumn{2}{c|}{ Loss of hedging } \\
\hline & & Min & Max & Min & Max \\
\hline $\mathrm{S}_{\mathrm{T}}<5.9$ & $-\mathrm{S}_{\mathrm{T}}-0.347$ & - & - & 0.347 & 0.347 \\
\hline $5.9 \leq \mathrm{S}_{\mathrm{T}}<6.2$ & $-2 \mathrm{~S}_{\mathrm{T}}+5.553$ & - & - & 0.347 & 0.647 \\
\hline $6.2 \leq \mathrm{S}_{\mathrm{T}}<6.847$ & -6.847 & - & - & 0 & 0.647 \\
\hline $6.847 \leq \mathrm{S}_{\mathrm{T}}$ & -6.847 & 0 & $\infty$ & - & - \\
\hline
\end{tabular}

Source: Authors' calculation 
In Figure 5 are shown the unhedged position and hedged wheat buying price level by Vertical Ratio Call Back Spread strategy. It is illustrative that hedged position ensured the same buying price ceiling.

Figure 5. Hedged and unhedged wheat buying price by Vertical Ratio Call Back Spread strategy

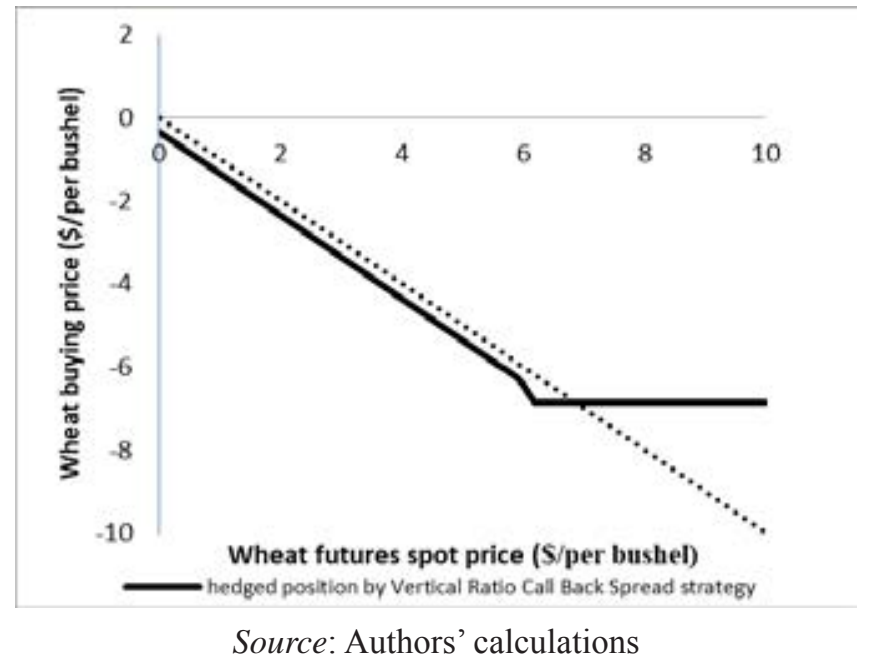

\section{Discussions}

There do not exist the effective hedging strategy for all market participants and their individual expectations about price moves. Every hedger in the market should understand how to evaluate and compare option hedging strategies with the respect to their advantages and disadvantages.

Figure 6 compares alternatives A and presents the wheat buying prices for potential wheat spot prices in the future.

Figure 6. Comparison of A hedged alternatives

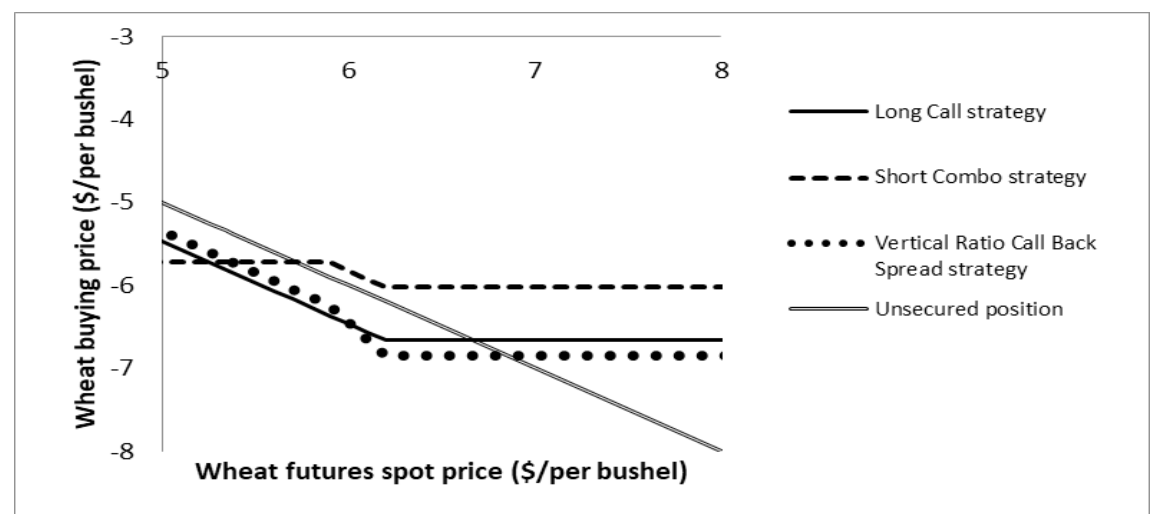

Source: Authors' calculations 
The comparison of wheat hedging alternatives A is presented in Table 10. In summary, the conclusions are:

- Hedging variant formed by Short Combo strategy secures the lowest wheat buying price if the wheat futures spot price is higher than $\$ 5.377$ per bushel but this strategy limits to profit in the wheat price decrease.

- Hedging variant formed by Vertical Ratio Call Back Spread strategy establishes the lowest wheat selling price if the wheat future spot price is lower than $\$ 5.377$ per bushel but the highest wheat buying price if the wheat futures price is higher than $\$ 6.138$ per bushel.

- $\quad$ Long Call strategy hedged the wheat buying price in the middle.

- The unsecured position offers better wheat buying price as others variants if the wheat futures price is lower than $\$ 5.724$ per bushel but does not secure the buying price level ceiling.

In summary, Short Combo strategy hedges the lowest buying price compared to others strategies. On the other hand, this strategy does not allow to participate in the price drop. The benefit is also the possibility of formation without any initial costs. Vertical Ratio Call Back Spread strategy establishes the buyer the highest wheat buying price in the case of price increase. If the wheat spot price decreases in the future than the Vertical Ratio Call Back Spread strategy participates proportionally with the unhedged variant. The loss is limited in the amount of negative difference from option premiums.

Table 10. Comparison of wheat buying prices of A hedged alternatives

\begin{tabular}{|c|c|c|c|c|c|c|c|c|}
\hline \multirow{2}{*}{ Wheat future spot range } & \multicolumn{2}{|c|}{ LC } & \multicolumn{2}{c|}{ SC } & \multicolumn{2}{c|}{ VRCBS } & \multicolumn{2}{c|}{ UP } \\
\cline { 2 - 9 } & Min & Max & Min & Max & Min & Max & Min & Max \\
\hline $0 \leq \mathrm{S}_{\mathrm{T}}<5.257$ & 0.467 & 5.724 & 5.724 & 5.724 & $\mathbf{0 . 3 4 7}$ & $\mathbf{5 . 6 0 4}$ & 0 & 5.257 \\
\hline $5.257 \leq \mathrm{S}_{\mathrm{T}}<5.339$ & 5.724 & 5.806 & 5.724 & 5.724 & $\mathbf{5 . 6 0 4}$ & $\mathbf{5 . 6 8 6}$ & 2.257 & 5.339 \\
\hline $5.339 \leq \mathrm{S}_{\mathrm{T}}<5.377$ & 5.806 & 5.844 & 5.724 & 5.724 & $\mathbf{5 . 6 8 6}$ & $\mathbf{5 . 7 2 4}$ & 5.339 & 5.377 \\
\hline $5.377 \leq \mathrm{S}_{\mathrm{T}}<5.724$ & 5.844 & 6.191 & 5.724 & 5.724 & $\mathbf{5 . 7 2 4}$ & $\mathbf{6 . 0 7 1}$ & 5.377 & 5.724 \\
\hline $5.724 \leq \mathrm{S}_{\mathrm{T}}<5.9$ & 6.191 & 6.367 & $\mathbf{5 . 7 2 4}$ & $\mathbf{5 . 7 2 4}$ & 6.071 & 6.247 & 5.724 & 5.9 \\
\hline $5.9 \leq \mathrm{S}_{\mathrm{T}}<6.0$ & 6.367 & 6.467 & $\mathbf{5 . 7 2 4}$ & $\mathbf{5 . 8 2 4}$ & 6.247 & 6.447 & 5.9 & 6.0 \\
\hline $6.0 \leq \mathrm{S}_{\mathrm{T}}<6.02$ & 6.467 & 6.487 & $\mathbf{5 . 8 2 4}$ & $\mathbf{5 . 8 4 4}$ & 6.447 & 6.487 & 6.0 & 6.02 \\
\hline $6.02 \leq \mathrm{S}_{\mathrm{T}}<6.138$ & 6.487 & 6.605 & $\mathbf{5 . 8 4 4}$ & $\mathbf{5 . 9 2 6}$ & 6.487 & 6.723 & 6.02 & 6.138 \\
\hline $6.138 \leq \mathrm{S}_{\mathrm{T}}<6.2$ & 6.605 & 6.667 & $\mathbf{5 . 9 2 6}$ & $\mathbf{6 . 0 2 4}$ & 6.723 & 6.847 & 6.138 & 6.2 \\
\hline $6.2 \leq \mathrm{S}_{\mathrm{T}}<\infty$ & 6.667 & 6.667 & $\mathbf{6 . 0 2 4}$ & $\mathbf{6 . 0 2 4}$ & 6.847 & 6.847 & 6.2 & $\infty$ \\
\hline
\end{tabular}

Source: Authors' calculation

Based on our methodology, the final Table 11 summarizes fundamental attributes of analyzed option hedging strategies. Potential hedgers should have knowledge about them considering their future expectations. 
Table 11. Attributes of option hedging strategies

\begin{tabular}{|l|c|c|c|c|c|}
\hline \multicolumn{1}{|c|}{ Option hedging strategy } & $\begin{array}{c}\text { Minimum } \\
\text { price }\end{array}$ & $\begin{array}{c}\text { Maximum } \\
\text { price }\end{array}$ & $\begin{array}{c}\text { Profit of } \\
\text { hedging }\end{array}$ & $\begin{array}{c}\text { Loss of } \\
\text { hedging }\end{array}$ & Zero-cost \\
\hline Long Call & unlimited & limited & unlimited & limited & no \\
\hline Short Combo & limited & limited & unlimited & unlimited & yes \\
\hline Vertical Ratio Call Back Spread & unlimited & limited & unlimited & limited & yes \\
\hline
\end{tabular}

Source: Authors' summary

All presented strategies provide the ceiling price level and can help to protect buyers from unreasonable losses. From the analyzed hedging strategies only the Short Combo strategy does not alove to participate in the price decrease. Short Combo strategy and Vertical Ratio Call Back Spread strategy can be formed as the strategies zero-cost. The conclusion is that using short options in combination with long options can protect against anticipated price movement without initial financial resources. Long Call strategy and Vertical Ratio Call Back Spread strategy hedge a price growth and speculate on a price decrease. It is valid that hedging does not guarantee that the profit or loss in the futures market will fully offset the loss or profit in the spot market. The choice of the strike prices is significant step of the hedging process. In addition, there exist other option strategies that can be used by hedgers in the price risk management against the price increase.

\section{Conclusions}

Every wheat buyer tries to make purchase at the lowest price. The issue is that futures prices cannot be predicted. Option strategies is often considered as an appropriate hedging strategy. Actually, there are not many agricultural buyers who use options in their business. For those who understand the mechanism of the options they can provide a flexible and effective instrument of price risk management. Options offer many possibilities of hedging the price risk.

The paper presented wheat risk management using option strategies. The aim was to analyze and compare option hedging strategies Long Call, Short Combo and Vertical Ratio Call Back Spread strategy. These strategies were applied in hedging of wheat, where was demonstrated the usage of hedging against increasing price in selected model variants. Fundamental characteristic of these strategies has been provided. Every strategy was described and profit/loss payoffs was designed. Our results showed that all presented strategies hedge the wheat buying maximum price level. The Long Call strategy establishes a maximum buying price for an option premium and simultaneously allow to participate in the price decrease. The zero-cost Short Combo strategy hedges the lowest ceiling price level but the possibility to participate in the price drop by establishing a floor price level. The ceiling-floor price spread is determined by the strike prices selection. The greater the difference between strike prices, the wider the ceilingfloor price spread. The Vertical Ratio Call Back Spread strategy eliminates price risk if the markets move upside with the possibility to participate in the price decrease. The buying price spread by the Vertical Ratio Call Back Spread strategy is not only defined by the strike prices but also by the numbers of options. 
Presented option strategies illustrate the possibilities of agricultural commodity hedging. The performed analysis and comparison have shown more remarkable findings which can be used in practical investment. Successful risk management with options is based on the ability of buyer to match an appropriate strategy to a particular price expectation in accordance with hedging objectives. This paper extends the previous research focused on hedging framework and it may be widened in further analysis.

\section{Conflict of interests}

The authors declare no conflict of interest.

\section{References}

1. Amaitiek, O.F.S., Bálint, T., \& Rešovský, M. (2010). The Short Call Ladder strategy and its application in trading and hedging. Acta Montanistica Slovaca, 15(3), 171-182.

2. CME Group, Chicago, Retrieved from http://www.cmegroup.com (October 14, 2020)

3. Cohen, G. (2005). The Bible of Options Strategies. Pearson Prentice Hall, New Jersey, USA.

4. Đordjevic, B. (2018). Hedging by Using Weather Derivatives in Winter Ski Tourism. Economics of Agriculture, 65(1), 125-142. https://doi.org/10.5987/ ekoPolj1801125D

5. Garcia, P., \& Leuthold, R.M. (2004). A selected review of agricultural commodity futures and options markets. European review of agricultural economics, 31(3), 235-272.

6. Harčariková, M., \& Bánociová, A. (2015). Analysis of using options to the express certificates' formation. Economic Research, 28(1), 354-366. https://doi.org/10.108 0/1331677X.2015.1043776

7. Harčariková, M. (2015). Proposal of new outperformance certificates in agricultural market. Agricultural Economics, 61(9), 400-409. https:/doi. org/10.17221/199/2014-AGRICECON

8. Harčariková, M., \& Šoltés, M. (2016). Risk Management in Energy Sector Using Short Call Ladder Strategy. Montenegrin Journal of Economics, 12(3), 39-54. https://doi.org/10.14254/1800-5845.2016/12-3/3

9. Harčariková, M., \& Šoltés, M. (2017). New hedging techniques in energy sector using barrier options. Acta Montanistica Slovaca, 22(4), 389-395.

10. Hull, J.C. (2009). Options, Futures, and Other Derivatives. 7th edition. Pearson Prentice Hall, New Jersey, USA.

11. Hull, J.C. (2011). Fundamentals of Futures and Options Markets. Global Edition, Pearson, London, UK.

12. Kolb, R.W. (1995). Understanding options. John Wiley \& Sons, Ltd., Hardcover. 
13. Kolb, R.W., \& Overdahl, J.A. (2010). Financial Derivatives: Pricing and Risk Management. JohnWiley \& Sons, Inc., New Jersey, USA.

14. Kuzman, B., Ercegovac, D., \& Momčilović, M. (2018). Development of derivative trading on financial market and agribusiness sector in Serbia. Economics of Agriculture, 65(2), 601-616. https://doi.org/10.5937/ekoPolj1802601K

15. Šoltés, V. (2002). Financial derivatives [in Slovak: Finančné deriváty]. EkF TUKE, Košice, Slovakia.

16. Šoltés, M., \& Harčariková, M. (2015). Analysis of Nova 1 strategy formed by barrier options and its application in hedging against a price drop in oil market. Acta Montanistica Slovaca, 20(4), 311-318. https://doi.org/10.3390/ams20040311

17. Šoltés, V., \& Harčariková, M. (2015). Analysis of Using Barrier Options to the Formation of New Structured Products. Mediterranean Journal of Social Sciences, 6(2), 303-311. https://doi.org/10.5901/mjss.2015.v6n2p303

18. Šoltés, M., \& Harčariková, M. (2016). Gold price risk management through nova 3 option strategy created by barrier options. Investment Management and Financial Innovations, 13(1), 49-60. https://doi.org/10.21511/imfi.13(1).2016.04

19. Šoltés, V., \& Harčariková, M. (2017). Design of new barrier outperformance certificates in oil market. Engineering Economics, 28(3), 262-270. https:/doi. org/10.5755/j01.ee.28.3.11481

20. Šoltés, V., Timková, M., \& Gičová, V. (2019). New Modifications of Express Certificates on Two Assets. Montenegrin Journal of Economics, 15(4), 113-129.

21. Taleb, N.N. (1997). Dynamic Hedging: Managing Vanilla and Exotic Options. Wiley \& Sons, Inc., New Jersey, USA.

22. Taušer, J., \& Čajka, R. (2014). Hedging techniques in commodity risk management. Agricultural Economics, 60(4), 174-182. https://doi.org/10.17221/120/2013AGRICECON

23. Timková, M. (2016). Investing in gold using reverse bonus sprint certificate. Scientific Papers of the University of Pardubice, 23(38), 31-42.

24. Timková, M. (2018). Managing price risk in the corn market using option strategies. Acta Universitatis agriculturae et silviculturae Mendelianae Brunensis, 66(3), 767-779. https://doi.org/10.11118/actaun201866030767

25. Timková, M., \& Šoltés, M. (2019). Managing the equity risk using Short Put Ladder strategy by barrier options. Investment Management and Financial Innovations, 16(4), 133-145. https://doi.org/10.21511/imfi.16(4).2019.12 
